\title{
Kompetence v environmentálním vzdělání
}

\author{
Jana Dlouhá \\ Envigogika 2009/IV/1 - Recenzované články/ Reviewed Papers \\ Publikováno/Published 31. 05. 2009
}

DOI: http://dx.doi.org/10.14712/18023061.34

\begin{abstract}
Abstrakt:
Vymezení pojmu, možnosti hodnocení vzdělávacích výstupů.

Text navazuje na obecný přehled transformačních procesů ve vzdělání a pracuje s dřive vymezeným pojmem kompetence, kterým se definují vzdělávací kvality $v$ tomto novém prostředí. Poskytuje prehled o aplikaci konceptu kompetencí v oblasti environmentální, diskutuje o posunech či možnostech, jež tento přístup otevírá pro rozvíjení vztahu mezi člověkem a jeho prostředím ve všech jeho dimenzích současně (tedy znalostních, afektivních a dovednostních, které při utváření kompetence spolupůsobí). Zabývá se nedostatečným rozpracováním teoretických základů konceptu kompetencí a dopady tohoto stavu pro rozvoj takové metodiky hodnocení výstupů vzdělávacího procesu, jež by zajistila porovnatelnost jeho výsledků a současně i soustavný rozvoj. Ukazuje současně podobnost obecných transformačních procesů a proenvironmentálních změn ve vzdělání, i možnosti praktického využití těchto tendencí.
\end{abstract}

\section{Klíčová slova:}

Environmentální vzdělávání (EV), kompetence v EV, posouzení

\begin{abstract}
:
Terminology and principles of assessment

The article is a follow-up to the general overview of the transformation process in education; it operates with the term competence that defines new educational qualities. It provides a review of environmental connotations of the term; the range of educational objectives related to the understanding of competences as complex (including cognitive, affective and psychomotor aspect) outcomes of the educational process that show its quality in action is discussed. Underdeveloped theory of this new outcome of the educational process has a negative impact on the clarity and practical usability of the concept: its consequences for evaluation and assessment are still relatively vague.
\end{abstract}

\section{Key words:}

Education for sustainable development (ESD), competences in ESD, assessment 


\section{Úvod}

Nové koncepce vzdělání přijaté na evropské úrovni mají současně naplňovat potřeby trvale udržitelného rozvoje. ${ }^{1}$ Podobnost ovšem nevychází čistě ze souběžnosti cílů, ale i z vnitřního souladu obecných principů formulovaných pro vzdělání budoucnosti, a těch, ze kterých vycházejí zásady environmentální výchovy a vzdělávání - viz tabulka 1.

Tabulka 1. Srovnání obecných zásad vzdělání budoucnosti s charakteristickými rysy vzdělání pro trvale udržitelný rozvoj.

\section{7 základních principů vzdělání budoucnosti, které jsou dosud ve vzdělávacích systémech zanedbány (Morin, 1999: 1-4):}

Odhalování chyb a iluzí - vědecké poznání, na které se spoléháme, když hledáme zdůvodnění pro naši vizi lidské existence, je dočasné a otevřené. Současné vzdělání však ignoruje podstatu lidského vědění, jeho psychologické a kulturní dispozice, které ho činí náchylným k chybám a iluzím.

Zásady přiměřenosti vědění - jak se naučit porozumět obecným, zásadním problémům a zařazovat zvláštní poznatky do jejich rámce. Zlomkovité učení rozdělené do disciplín nám znemožňuje propojovat celky a části; mělo by být nahrazeno učením, které zařazuje subjekty do kontextu, do jejich komplexu. Měli bychom učit metodám, jak zařadit vzájemné souvislosti a vlivy do částí a celku komplexního světa.

Humánní podstata by měla být základním cílem celého vzdělání. Složitá povaha lidství byla tak důkladně rozčleněna do jednotlivých předmětů poznání, že nyní je třeba znovu vytvořit komplexní vědomí jednoty a sdílené podobnosti sjinými lidskými bytostmi.

\section{Charakteristické rysy vzdělání pro trvale udržitelný rozvoj; to by mělo být (Sterling, 1996: 22-24):}

Inovativní a konstruktivní - inspirovaná novým paradigmatem postmoderního myšlení

Cílevědomé - zkoumá, testuje, kritizuje a pěstuje hodnoty a alternativy, jež mají napomoci změně.

Učení v souvislostech ekonomických, sociálních ekologických a komunitních a také regionálních, národních, mezinárodních a globálních

Orientované na proces získávání dovedností a znalostí spíše než na jeho výsledek vzdělání se stává nezbytností pro život. Je tedy spíše participativní než pasivní, dưraz je na učení spíše než na výuce. Neodmyslitelný je akční výzkum, který zdůrazňuje kritickou reflexi, učení prostřednictvím zkušenosti a demokratické zásady.

Humánní - v centru pozornosti je student; toto vzdělání funguje nejlépe, když vyhovuje potřebám studentů i učitelů.

Založené na holistickém přístupu - všechny vzdělávací dimenze by měly být konzistentním celkem; měla by být utvářena ucelená bytost člověka.

\footnotetext{
1 Viz např. Recommendation of the European Parliament and of the Council, 18 December 2006 on key competences for lifelong learning (2006/962/EC) [Online] [Cit-2009-03-03] Dostupné z www: <http://eur-lex.europa.eu/LexUriServ/site/en/oj/2006/l 394/I 39420061230en00100018.pdf>

zde není udržitelný rozvoj jedním z hlavních principù, je ale součástí definice hlavních kompetencí (zahrnují jej vědecké kompetence, sociální a občanské kompetence): "Scientific competence includes an attitude of critical appreciation and curiosity, an interest in ethical issues and respect for both safety and sustainability, in particular as regards scientific and technological progress in relation to oneself, family, community and global issues". Social and civic competences include "Full respect for human rights including equality as a basis for democracy ...This means displaying both a sense of belonging to one's locality country, the EU and Europe in general and to the world... Constructive participation also involves civic activities, support for social diversity and cohesion and sustainable development, and a readiness to respect the values and privacy of the others."
} 
Jednota světa je další základní skutečností, která je ve vzdělání zanedbána. Jsme nyní občany jednoho světa a všechny jeho části jsou na sobě vzájemně závislé. Měla by být objasňována komplexní podstata planetární krize 20. století, která je naším společným osudem.

Vzdělání by mělo naučit čelit nejistotám, které jsou součástí všech vědních disciplín. Deterministické teorie lidských dějin již neplatí; vzdělání se stává uměním navigovat $v$ moři neurčitostí, při plavbě kolem a po ostrůvcích jistot. To souvisí s nárůstem dostupných informací ve všech oblastech.

Vzájemné porozumění ve všech ohledech vyžaduje změnu mentality. Přenese nás však přes současnou barbarskou epochu neporozumění.

Etika, kterou nelze učit lekcemi morálky. Je spíše vědomím individuální, prírodní a společenské povahy lidství.
Integrující - založené na interdisciplinárním či transdisciplinárním výzkumu, který reflektuje vzájemné vztahy. Transdisciplinarita je vytvářením nových významů, chápání a nových metod práce.

Systémové a propojující - zdůrazňuje vztahy a modely, vytváří vědomí provázanosti a vede k,moudrosti".

Kritické - nikoli extrémní, ale čerpající z různých názorových proudů.

Vyvažující - hledá rovnováhu mezi souvisejícími jevy rozdělenými dominujícím dualistickým paradigmatem. Zahrnují znalosti a hodnoty, intelektuální a citovou výchovu, racionalitu a intuici, objekt a subjekt, hmotné a duchovní; ekonomii a ekologii atd.

Etické - vyjasňuje etické problémy, zvyšuje citlivost - rozšiřuje smysl pro okamžitou a osobní užitečnost na vědomí solidarity se vzdálenými společenstvími a jevy. Není ani monistické, ani relativistické, ale reflektuje ekologický pluralismus.

Není selektivní, je celoživotní - pro všechny lidi nezávisle na věku.

\section{Kategorie obecných kvalit}

Realistické cíle environmentálního vzdělání zahrnují pěstování určitých kvalit, které jsou na obecné rovině definovány následujícím způsobem:

- kognitivní kvality jako např. schopnost syntézy částí do komplexních celků, objevování vzorců v komplexních údajích nebo pohlížení na situace z různých úhlů. Studenti by měli být schopni pojednat problém interdisciplinárně - to je možné nejlépe při práci na konkrétní (teoretické či praktické) úloze, jejiž řešení vyžaduje spolupráci více oborů. ${ }^{2}$ Je třeba vytvořit znalosti nutné pro identifikaci problémů, jejich definici a zacházení s nimi.

- emoční kvality jako je zájem o své okolí (prostředí);

- "akční" kvality jako nezávislost, pružnost, schopnost vyvinout iniciativu a přijmout odpovědnost za své činy, a uskutečnit akce k řešení reálných problémů (životního

\footnotetext{
2 Nástrojem řešení environmentálních otázek je interdisciplinární metodika integrovaného poznání, která vznikla jako odpověd’ na krizi moderní racionality. Environmentální vzdělání absorbovalo nové paradigma komplexity prostřednictvím holistického přístupu k realitě a interdisciplinární re-kompozice vědění (Leff, 1977) ... Environmentální interdisciplinarita není ani součtem ani jiným členěním disciplín; nemůže jí být dosaženo mimo základní paradigma vědy jakožto čisté hry komplexního myšlení. Environmentální vzdělání vyžaduje konstrukci nových interdisciplinárních objektů studia, a transformaci převažujících paradigmat. Není jednoduché navrhnout a realizovat environmentální vzdělávací programy - tento proces nemůže totiž být pouhou kombinací disciplín za účelem vytvoření multi-tematického programu (Leff, 1977) ...Environmentální principy a hodnoty by měly být obohaceny výukou komplexního myšlení, která by vytvořila u studentů schopnost analyzovat mnohonásobné závislosti a vazby a která by podpořila kritický a kreativní přístup využivající nové kapacity poznání (Leff, 1977)
} 
prostředí ve svém okolí). V důsledku toho je student schopen převzít iniciativu v plánování svého učebního procesu a těžit z rozmanitých zkušeností.

- $\quad$ umění rozlišovat hodnoty obecné i dílčí, např.:

- při posuzování informací. To zahrnuje základní orientaci v „informačním terénu" a zvládnutí práce $s$ textem ve všech jeho podobách a na různých médiích, které mohou být jeho nosiči. Je třeba umět hodnotit kvalitu informací (obecnou platnost, pravdivost ${ }^{3}$ ) a relevanci (hodnotu pro daný úkol - užitečnost pro práci na určitém okruhu otázek)

- při hledání priorit a cílů. Studenti by měli považovat znalosti za materiál, ze kterého budují svá díla. O tom, jaká díla budou vytvářet, by se měli umět rozhodovat svobodně (tvořivě) a $v$ závislosti na obecně platných hodnotách či normách a v souladu s vlastními životními prioritami. Z tohoto důvodu by $\checkmark$ průběhu studia měla být věnována pozornost dovednosti stanovit si cíle (osobní, profesní, obecně humánní,...) a volit strategie k jejich uskutečnění ${ }^{4}$.

jiné typy kvalit, které uvádějí další autoři, a které by měly být v environmentálním vzdělání rozvíjeny, zahrnují reflexivní kvality: spočívající v umění monitorovat své aktivity ve vztahu k okolí (životnímu prostředí). Jejich teoretickým podkladem je teorie reflexivní akce (Schön, 1983).

umění reflektovat současný stav by mělo být vyváženo schopností předjímat budoucnost - anglosaská literatura tento aspekt považuje především za důležitou součást konceptu udržitelného rozvoje a nazývá jej „vizionářství" (Sleurs, 2004: 27).

\section{Kompetence jako kvality environmentálního vzdělání?}

Jak jsme ukázali v článku "Obecné vzdělávací kvality a pojem kompetence", teoretickým základem pro edukační proces a stanovení vzdělávacích cílů je tradičně tzv. Bloomova taxonomie (1956), která hrála svou roli i v našem školství: přihlíželo se k ní při tvorbě národních vzdělávacích strategií. Její význam spočívá v tom, že poskytuje hlavní kategorie pro plánování výukových obsahư a metod (tvorbě cílů), pro hodnocení, a také nástroje pro hledání souladu mezi cíli, instrukcemi a hodnocením. V současnosti je ovšem patrný výrazný posun $v$ kategorizaci a hodnocení těchto cílů: z původního členění na oblast kognitivní, afektivní a psychomotorickou se důraz posunul na kombinace těchto jednotlivých složek či kvalit a to, jak se osvědčují při svém užití, v konkrétní akci. $\mathrm{S}$ přesunem akcentu $\mathrm{k}$ více dynamickému pojetí vzdělávacích cílů je spojen pojem kompetence, jež v sobě zahrnuje jednotlivé složky (tedy znalosti, dovednosti a postoje) a je spojen se situací, v jejímž rámci se taková kombinace schopností uplatňuje. Podobný postup při stanovení žádoucích výstupů vzdělávacího procesu může dobře sloužit i pro vymezení cílů $v$ oblasti environmentální: právě proto, že zde nemá být pěstována pouze teoretická znalost, ale soubor schopností uskutečnit akci se zamýšleným výsledkem.

\footnotetext{
3 Tedy pravdivost výpovědi $v$ jí často implicitně deklarované úrovni obecnosti. Závislost pravdy na kontextu výpovědi nás nezbavuje odpovědnosti zkoumat výroky, které překračují hranice toho diskursu, ve kterém vznikly $a \vee$ němž jsou opodstatněné na základě určitých zákonitostí či pravidel, a činí si nárok na platnost obecnou - právě naopak.

4 „„... Environmentální vzdělání též podporuje vytváření osobního vědění, které je subjektivním vstupem do světa komplexity. Důsledkem toho je, že neexistuje pevné a jednou provždy dané vědění, které je přeneseno a instalováno do myslí studentů; vzdělávací proces spíše studentům umožňuje konstruovat pojmy na základě primárních významů. Z této vzdělávací perspektivy se učení stává přizpůsobováním obecného poznání subjektivní potřebě a smyslu, a to prostrednictvím kritického a komplexního myšlení." (Leff, 1977)
} 
Pojem kompetence obecně je ovšem velmi široký a tak je třeba jej upřesnit podle toho, jaké jsou skutečné cíle toho kterého kurzu, programu, vzdělávací oblasti atd. Tedy také ve sféře, kterou se dále budeme zabývat, ve vzdělání environmentálním (ESD), se tzv. klíčové kompetence popisují různě: především musí být jasně rozlišeny od vzdělávacích obsahů (hlavních problémů životního prostředí a/nebo environmentálních disciplin, které se jimi zabývají), a od klíčových konceptů, které se uplatňují v interdisciplinárních a transdisciplinárních vztazích v rámci studijních programů a kurikula (definovaných např́klad jako: komplexita, nejistota, limity, evoluční procesy, pružnost systému, životní cyklus, práh rizika, únosná kapacita atd.) (Mayer, Losito, 2008: 1).

Pojem kompetence (jemuž je i zde rozuměno rưzně) nesmí být také zaměňován s pojmy "kvalifikace" nebo "standard". Kompetence mají komplexní a holistickou povahu: komponenty znalostní, kognitivní, dovednostní, a také sociální a behaviorální, jež zahrnují schopnosti, emoce, hodnoty a motivace. Pojem kompetence není možné redukovat na jednu z těchto dimenzí (Sleurs, 2004: 39). Mají svou vnitřní strukturu; její určení může pomoci definovat předpoklady nutné pro získání, dosažení té které žádoucí kompetence, tedy vybrat vhodnou metodiku, vzdělávací prostředí atd (UNECE, 2008: 4).

Je otázkou, zda existují kompetence specifické pro vzdělání environmentální (ESD). Mckeown (2002) popisuje znaky tohoto typu vzdělání a rozlišuje mezi znalostmi, dovednostmi, perspektivami, hodnotami a problémy: ty je třeba je vzít do úvahy, když se vzdělávací program transformuje ve směru udržitelnosti (Sleurs, 2004: 40). K těmto důležitým aspektům ESD přidává koncept kompetencí aktivní dimenzi: cíle učení zaměřuje na identifikaci problémů a hledání řešení. Další autoři (Wilson-Hill et al) se pokusili na tomto základě určit akční kompetence v ESD a vytvořit tak analytický rámec pro jejich uchopení - analýzu a využití. Vycházeli z následujících komponent, součástí akčních kompetencí $v$ ESD připravovaných pro národní kurikulum na Novém Zélandě: vize budoucnosti, znalost (o prostředí), zkušenost (pocity a reakce), reflexe, pocit sounáležitosti (conectedness), akce přímé a neprímé. Tyto složky ukazují, jak člověk cítí, myslí a jedná, zda je ve vnitřním souladu a harmonii (coherence).

Kompetence, které jsou součástí Strategie EHK OSN pro vzdělávání pro trvale udržitelný rozvoj (Strategie UNECE, 2005) vycházejí ze čtyř pilírư vzdělávání pro 21. století (Delors, 1997) a rozvíjejí je do kompetencí využitelných na různých stupních formálního systému - viz tabulka 2 v př́loze.

O tom, jak mají být nové kompetence vymezeny, probíhá v současné době široká diskuze: jsou pokusy je definovat např́klad jako systémové myšlení, předjímání budoucnosti (visioning), kritický pohled (using multiple perspectives) a řešení problémů (UNECE, 2008c: 3).

Návrh na obecnou kategorizaci kompetencí zahrnuje následující složky (Sleurs, 2008), viz též obr. 1 :

1. Kompetence znalostní

2. Systémové myšlení (zahrnuje komplexní pohled, to, co je často nazýváno „holismem", ...)

3. Hodnoty, etika

4. Emocionální složka osobnosti

5. Akční kompetence 
Obr. 1 Kompetence ve vzdělávání ESD (Sleurs, 2008).

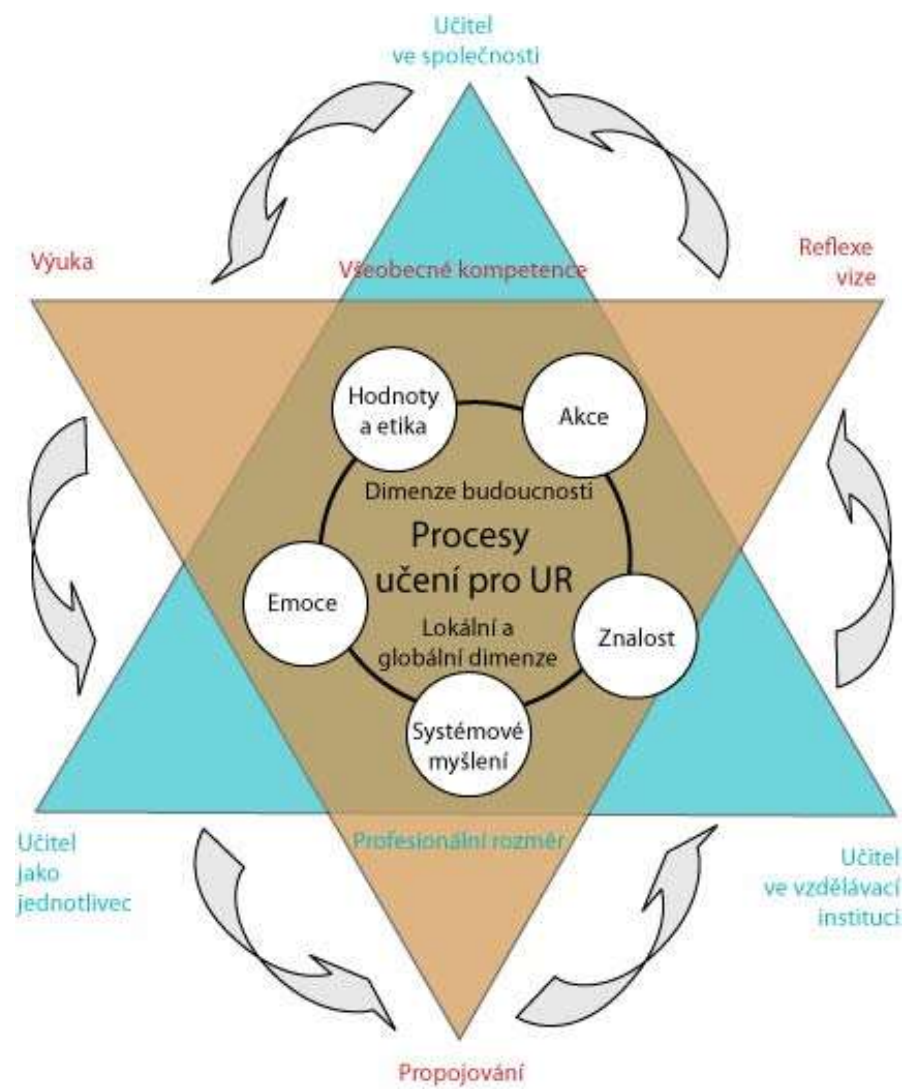

\section{Srovnání tradičních vzdělávacích cílů s kompetencemi pro ESD}

Bloomova taxonomie, jež poskytuje tradiční a názorné členění vzdělávacích cílů na znalosti, dovednosti a postoje, $v$ současnosti prochází revizí - výrazně se upřednostňuje více komplexní a cílům formálního vzdělání odpovídající kognitivní doména. Revidované pojetí taxonomie (Lorin et al, 2001 In: Hudecová, 2004)5, které právě tuto doménu pokládá za nejdůležitější, pod ni zahrnuje i cíle náležejíć pod doménu afektivní i psychomotorickou. Navrhuje se zde pouze jeden, zato však dvoudimenzionální koncept vzdělávacích oblastí: v něm znalostní dimenze zahrnuje čtyři kategorie (faktickou, konceptuální, procedurální a metakognitivní), dimenze kognitivního procesu je tvořena šesti kategoriemi (zapamatovat, porozumět, aplikovat, analyzovat, evaluovat, tvořit). Tím se kognitivní doména stává základním rámcem pro navrhování a posuzování vzdělávacích cílů. Její povaha se mění na více dynamickou (což je vyjádřeno v dimenzi kognitivního

\footnotetext{
${ }^{5}$ Podrobněji viz přímo citovaný text: Hudecová, D.: Revize Bloomovy taxonomie edukačních cílů.
} 
procesu). Nově zahrnuje kategorii tvorby 6 , která v původní kognitivní doméně vystupovala jako syntéza. Významný je posun od kumulativní hierarchie (stále složitější myšlenkové operace $v$ jednotlivých stupních kognitivní domény) ke komplexitě (vyšší stupně se vyznačují větší samostatností při usuzování či plánování). Terminologicky je znalostní dimenze uváděna vždy jako podstatné jméno, dimenze kognitivního procesu jako sloveso; formulace vzdělávacího cíle je tak zpravidla tvořena spojením obou, tedy slovesa a podstatného jména.

Všechny tyto posuny ve směru dynamického pojetí všeobecných vzdělávacích cílů mají svou paralelu ve formulaci kompetencí jakožto hlavních výstupů environmentálního vzdělání (ESD). To je patrné ze srovnávací tabulky, kde pưvodní, nerevidovaná taxonomie kognitivních cílů je popsána vedle kompetencí $v$ oblasti učení stanovených jako základ vzdělání environmentálního (ESD) - viz tabulka 3.

Tabulka 3. Srovnání kognitivní domény s návrhem kompetencí v oblasti učení pro environmentální vzdělání v dokumentu svázaném se Strategií ESD UNECE.

\begin{tabular}{|c|c|}
\hline Kognitivní doména (Bloom, 1956) & Učit se poznávat (UNECE, 2008b) \\
\hline $\begin{array}{l}\text { Znalost - znalosti konkrétní, znalosti } \\
\text { způsobư nakládání a operací } \\
\text { s konkrétními poznatky; } \\
\text { a znalosti obecnin a abstrakcí }\end{array}$ & $\begin{array}{l}\text { Kladení analytických otázek / kritické } \\
\text { myšlení }\end{array}$ \\
\hline $\begin{array}{l}\text { Pochopení - překlad } \\
\text { (= přenášení konceptů a myšlenek do } \\
\text { jazyka jiného oboru, do jiných pojmů...), } \\
\text { interpretace a extrapolace }\end{array}$ & $\begin{array}{l}\text { Porozumění komplexitě / systémové } \\
\text { myšlení }\end{array}$ \\
\hline $\begin{array}{l}\text { Aplikace - aplikace, transfer } \\
\text { (přenos a uplatnění poznatků v jiném } \\
\text { prostředí), schopnost činit závěry }\end{array}$ & Překonávání obtíží / řešení problémů \\
\hline $\begin{array}{l}\text { Analýza - analýza prvků, vztahů } \\
\text { a organizačních principů }\end{array}$ & Zvládání změn / kladení otázek \\
\hline $\begin{array}{l}\text { Syntéza - produkce jedinečného sdělení, } \\
\text { tvorba plánu nebo návrhu pořadí } \\
\text { operací, odvození souboru abstraktních } \\
\text { vztahů }\end{array}$ & $\begin{array}{l}\text { Tvưrčí myšlení / myšlení orientované na } \\
\text { budoucnost }\end{array}$ \\
\hline $\begin{array}{l}\text { Evaluace - posouzení na základě vnějších } \\
\text { kriterií nebo interních prvků }\end{array}$ & $\begin{array}{l}\text { Pochopení mezioborových vztahů / } \\
\text { holistický přístup }\end{array}$ \\
\hline
\end{tabular}

Tyto posuny a revize kognitivních kategorií modifikující původní koncept souvisí $\mathrm{s}$ přijetím mezioborového paradigmatu poznávání: Bloomovy cíle $\mathrm{v}$ podstatě sledovaly poznávací pohyb od pouhého faktu k teoretickému chápání, rozvoji metodologie; od nižších rozumových schopností k vyšším. Do této hierarchie lze obtížně zařadit pochopení mezioborových souvislostí, protože to většinou není založeno na nějakém zobecnění nebo dokonce metodě, ale spíše na analogii nebo praktickém hledisku. Na druhé straně kategorie učení v oblasti environmentální vycházejí z interdisciplinárního pojetí a jsou tak bližší právě novějšímu, revidovanému pojetí.

6 Tvořit znamená: vytváření nových vnitřně soudržných celků z jednotlivých prvků, reorganizace prvků do nového znaku nebo struktury (vytváření; plánování; tvorba) 
Ještě daleko větší změny oproti tradičnímu členění vzdělávacích cílů vymezených pomocí Bloomovy taxonomie se projevují v oblasti hodnotové, afektivní. Přehled $v$ tabulce 4 uvádí četné cíle (vytipované v rámci expertní skupiny UNECE pravděpodobně metodou „brainstormingu"), z nichž je patrný zásadní posun v chápání hodnot: nejde již o jejich „přijetí", ale o daleko větší odpovědnost za jejich samostatné vytváření a uplatňování. To souvisí s decentralizací odpovědnosti v rámci vzdělávacího procesu (i občanského života) obecně.

Tabulka 4. Srovnání afektivní domény s návrhem kompetencí v oblasti bytí a společenského života, jak byly vymezeny pro environmentální vzdělání v dokumentu svázaném se Strategií ESD UNECE.

\begin{tabular}{|c|c|}
\hline $\begin{array}{l}\text { Afektivní doména (Kratwohl et al, } \\
\text { 1973) }\end{array}$ & $\begin{array}{l}\text { Učit se být, učit se žít společně (UNECE, } \\
2008 \text { b) }\end{array}$ \\
\hline $\begin{array}{l}\text { Přijímání - ochota přijímat nebo vnímat } \\
\text { určité jevy: pozorovat je, tolerovat je, } \\
\text { nevyhýbat se jim. }\end{array}$ & Sebejistota \\
\hline $\begin{array}{l}\text { Reagování - větší zainteresovanost a více } \\
\text { aktivní prístup k určitým jevưm než na } \\
\text { úrovni přijímání. }\end{array}$ & Sebevyjádření a komunikace \\
\hline $\begin{array}{l}\text { Oceňování hodnoty - schopnost oceňovat } \\
\text { určité skutečnosti jako žádoucí; člověk } \\
\text { začíná pocitovat závazek k této hodnotě, } \\
\text { ta začíná ovlivňovat jeho jednání. }\end{array}$ & Vyrovnávání se se stresem \\
\hline $\begin{array}{l}\text { Integrování hodnot - schopnost } \\
\text { organizovat všechny přijaté hodnoty do } \\
\text { určité struktury; uvědomění, které hodnoty } \\
\text { jsou zásadní. }\end{array}$ & Určit a vyjasnit hodnoty \\
\hline $\begin{array}{l}\text { Zvnitřnění, internalizace hodnot - na } \\
\text { nejvyšší úrovni získávají hodnoty pevné } \\
\text { místo v hodnotovém žebříčku jedince } \\
\text { a dlouhodobě ovlivňují jeho chování } \\
\text { a jednání. }\end{array}$ & Jednání s odpovědností \\
\hline & Jednání s respektem k druhým \\
\hline & $\begin{array}{l}\text { Určení zainteresovaných osob (skupin) } \\
\text { a jejich zájmü }\end{array}$ \\
\hline & Spolupráce/práce v týmu \\
\hline & Účast v demokratickém rozhodování \\
\hline & Vyjednávání a vytváření konsenzu \\
\hline & Distribuce odpovědnosti (subsidiarita) \\
\hline & Sebejistota \\
\hline & Sebevyjádření a komunikace \\
\hline & Vyrovnávání se se stresem \\
\hline & Kompetence ESD (Sleurs, 2004) \\
\hline & Emoční kompetence \\
\hline & Akční kompetence \\
\hline
\end{tabular}


Je třeba připomenout, že $v$ revidované verzi Bloomovy taxonomie afektivní složka v pưvodní podobě nevystupuje: je pouze součástí kognitivních cílů, např́íklad $v$ podobě motivace k učení. Argumentuje se tím, že s afektivní doménou se hưre pracuje, například tyto cíle Ize obtížně plánovat, a tedy není ani příliš využívána. Dá se očekávat, že právě tento přístup se bude $v$ nejbližší době nejvýrazněji měnit: afektivní složka již rozhodně není spíše doprovodný jev a podmínka učení, jeho vnitřní motivace - je významná pro samostatné rozhodování, akci, ve které se jiné složky učení aktivují jakožto kompetence (více o afektivním základu jednání viz Dlouhá, 2007b). Pravděpodobně i z tohoto důvodu autoři „revize" nevylučují, že by mohla být teorie a na ní založená kategorizace pro ostatní domény dopracována (Hudecová, 2004). Podobné úvahy a tendence mohou znamenat stále větší prorůstání domén a jejich dílčích cílů (jak se děje i v samotných kompetencích) nebo také určitý filosofický posun oproti př́liš autoritativnímu pojetí hodnot v pưvodní verzi taxonomie, které $v$ praxi znamená ochotu se ztotožnit se zvolenou autoritou nebo standardem. Starší přístup významně odporuje myšlence decentralizace odpovědnosti (která je jedním z filosofických základů konceptů kompetencí a je také důležitým organizačním principem postmoderního světa7) a je v teorii i praxi postupně nahrazován méně hierarchickým př́stupem.

Z našeho posuzování byla vyňata doména psychomotorická (viz tabulka 5 v prríloze $\left.{ }^{8}\right)$, nebot' se vyznačuje nejnižší ujasněností; není ani hlavním předmětem zájmu tohoto textu, ačkoli v oblasti environmentální by jistě našla své uplatnění.

\section{Nejistoty spojené s kompetencemi a jejich hodnocením}

Dospěli jsme k závěru, že kvalita ve vzdělávání má být stále více posuzována jako míra dosažení velmi komplexních vzdělávacích cílů - kompetencí. To může narážet na tradiční pojetí, kdy plánování procesu výuky se zaměřuje spíše na vstupy: obsahy, procesy a metody, sice s ohledem na cíle, ty jsou však spíše jen vzdálenou vizí, ke které výuka směřuje. $V$ současnosti probíhají debaty o výhodách tzv. input versus outcome filosofie při posuzování procesu vzdělání a hodnocení jeho výsledků; mluví se dokonce o takto založených vzdělávacích "kulturách". V případě outcome přístupu jsou přednosti spatřovány $v$ decentralizaci odpovědnosti: např́klad pokud za žádoucí výstup pokládáme kompetence - vzdělávací kvalitu, která se stále významněji prosazuje - pak to má také dopad na přesun odpovědnosti za rozvoj vlastní profesionality i procesu učení na samotného učitele a studenta. Někdy jsou ale kritizována negativa tohoto úhlu pohledu: důraz na hodnocení "výstupů" a jejich měření může souviset s ekonomickým myšlením, vzdělávací politikou, jež má být efektivní, a kulturou auditů, přičemž tento způsob hodnocení neříká nic o reálných praktikách ve výuce...

Představa kompetencí jako významného vzdělávacího cíle je tak z různých důvodů často diskutovaným konceptem. Re-orientace na vzdělávací výstupy spíše nežli na vstupy představuje určitou „změnu paradigmatu", která se pak musí projevit i ve změně způsobů hodnocení. Pokud se tak nestane, bude představa kompetencí jen módním výrazem bez obsahu (Sleurs, 2004: 34, 36).

\footnotetext{
7 Jde o teoretické úvahy Ulricha Becka, Anthony Giddense, nebo Zygmunta Baumana, kteří hovoří o novém uspořádání společnosti, tzv. tekuté modernitě. $V$ ní se hroutí tradiční vertikální vztahy a zaběhnuté jistoty ve prospěch horizontálních sítí a individuálních vztahů, které je nutné neustále znovu potvrzovat $v$ jakémsi permanentním dialogu. $V$ systému institucionální organizace na různých úrovních jde $\mathrm{v}$ tomto prípadě především o partnerství, které má být protikladem ke klasickému systému vztahů založených na mocenských hierarchiích. Partnerství předpokládá spolupráci $v$ rámci horizontálních sítí spíše než vertikální dominanci. Viz též (Pehe, 2006)

8 Psychomotorickou doménu do této analýzy nezahrnujeme, její cíle tak, jak byly definovány původně, se málo používají, pokusy o jinou definici většinou znamenají, že do této oblasti jsou umístěny cíle, které se "jinam nehodí", výsledkem je překryv rưzných domén a zvyšování míry neujasněnosti namísto jasného rozčlenění, k němuž kategorizace má směřovat: viz tabulka - př́loha 2.
} 
$\mathrm{Na}$ tom, jak kompetence hodnotit, se ale již teoreticky pracuje. Allen et al (2005) zabývající se kompetencemi ve vysokoškolském vzdělání vypracovali model pro evaluaci kontextově neutrálních akčních kompetencí, které jsou pak definovány jako předpoklady účinné akce. Protože kompetence nebyly $v$ literatuře přesně specifikovány (resp. pro samotné kompetence existuje více pojetí, a tedy význam tohoto obecného pojmu se rưzní v závislosti na kontextu), je nutné se v první fázi ptát na jejich účel: definovat ty (pracovní) funkce a role, pro něž jsou kompetence nezbytné. Tak výše uvedení autoři určili devět širších kategorií aktivit relevantních pro určité (pracovní) situace (Jde o situace, v nichž se mohou ocitnout absolventi různých typů vysokých škol a jsou vymezeny takto: řízení vlastní práce, organizace práce druhých, plánování, koordinace, kontrola, inovace, práce s informacemi, osobní vztahy, vztahy s klienty). Pak je možné se ptát, jaké znalosti, dovednosti a motivace se $v$ určité kategorii pravděpodobně uplatní - na základě toho Ize vytvořit dvojrozměrnou matici pro hodnocení úspěšnosti vzdělávacího procesu. Problémem ovšem je komplexita reálných situací i podmínek jejich úspěšného zvládnutí: pro určitou akci je často třeba více kategorií kompetencí, a naopak, některé kompetence jsou předpokladem zvládání různých akcí.

Díky tomu, že každá kompetence je definována jako soubor určitých znalostních, afektivních a dovednostních komponent (kompetence mají komplexní povahu, kterou Ize vyjádřit pomocí starších kategorií), je možno $v$ teoretické rovině pracovat $s$ jejich nejdůležitějšími součástmi, přiřadit jim určité charakteristiky a zařadit je na určité roviny pozorování. Kompetence jsou tak vizuálně diferencovány na jisté dispozice (individuální dispozice charakterizované jako schopnosti, hodnoty, motivace atd.); situace, v nichž se projevují (komplexní, nerutinní, dynamické); a standardy pro vhodné chování (výsledek sociálního konsenzu, jehož dưsledkem je vhodnost a odpovědnost chování). Úrovně pozorování pak současně představují rozdílná teoretická hlediska, kterými Ize složku popsat (pohled psychologický, hledisko akčních teorií, sociologický přístup). Popsané komponenty či faktory (dispozice, situace, sociální standardy \& jejich charakteristiky) hrají roli $v$ rozvoji kompetence, který se pak uskutečňuje $v$ pěti stádiích či krocích: od získání informace, nabytí určité znalosti a schopnosti, přes kombinaci s hodnotami a motivacemi, akci (projev) spojenou s danou kompetencí až po profesionalizaci, jež vzniká zapojením odpovědnosti. Rưzná stádia Ize popsat jazykem psychosociálních teorií, akčních teorií nebo sociálních teorií (Schneckenberg \& Wildt, 2006).

Uvedení autoři takovou dekompozici kompetencí doporučují, umožňuje totiž redukovat komplexní problém na problémy dílči a ty poté studovat; zabývat se například otázkou, jakým zpưsobem spolu jednotlivé kompetence interagují, zda existují kompetence základní a nezbytné pro rozvoj dalších, jak obecně se kompetence rozvíjejí a uplatňují a kde se tak děje (zda v procesu výuky nebo v praktickém životě). Teprve pak bude možné takové jejich hodnocení, jež přinese impulsy také vzdělávací praxi. O tom, že pokusy o takové hodnocení spojené s transformačními procesy jsou realizovány, existují četné doklady (např. Wilson-Hill et al).

\section{Závěr}

Pojítkem, které koncept kompetencí činí nepostradatelnou součástí environmentálního vzdělání, je právě teorie: především tzv. dynamická kultura učení, v jejímž rámci se kvalita znalostí, dovedností a hodnot posuzuje $v$ procesu jejich vzniku a uplatnění, přičemž odpovědnost za aktivity $s$ tím související je do značné míry decentralizována. Takto je environmentální vzdělání integrální součástí transformačních procesů ve vzdělání, které navíc pomáhá prosazovat, má totiž některé rysy vzdělání pro budoucnost. Společné atributy by měly znamenat, že prvky nebo principy environmentálního vzdělání najdou široké uplatnění ve všech oblastech kurikula, a rozvoj jeho hlavních metodologických nástrojů bude relevantní nejen pro oblast životního prostredí. 
„Prosazování ekologické uvědomělosti ve školách je často spojováno s konzervativním duchem a nepřátelstvím vưči ekonomickému a technologickému vývoji. $\mathrm{Na}$ druhé straně, rozvinutí dynamických kvalit v myšlení studentů bude velmi významné pro ekonomický a technologický rozvoj společnosti. Dynamické kvality jsou neoddělitelné od environmentálního uvědomění ... [to] vede $\mathrm{k}$ vytváření potenciálu pro tvořivost, inteligenci a organizační dovednosti." (Elliot, 1991: 25, 27; Posch, 1994: 21).

O tom, že koncept kompetencí jakožto teoretický základ pro posuzování vzdělávacích kvalit propojuje cíle environmentálního vzdělání a jeho pokračující vývoj $\mathrm{s}$ dalšími transformačními procesy $v$ celém vzdělávacím systému, svědčí dokumenty přijaté v současné době na úrovni ČR i EU. ${ }^{9}$ Prokazatelná souvislost mezi oběma typy změn ve vzdělávacích systémech, $v$ nichž roli žádoucích kvalit či výstupư hrají kompetence, současně znamená, že na tomto koncepčním základě Ize založit hodnocení výsledků ESD. Pro posuzování takto definovaných vzdělávacích kvalit je třeba hledat praktické evaluační nástroje, které by pak probíhající změny či inovace postavily na objektivní a srovnatelný základ.

To ovšem prozatím naráží na četné metodologické problémy. Koncept kompetencí se právě v oblasti environmentální vyznačuje velkou diverzitou pojetí, různorodými pojmy i prioritami. Z tohoto důvodu se kompetence mohou stát prozatím velmi dobrým nástrojem především pro plánování výuky - rưznorodých, dané situaci i kontextu odpovídajících programů směřujících vždy k jinak ( $v$ kontextu dané situace) definovaným cílům. Je vhodné o nich uvažovat všude tam, kde jde o decentralizaci odpovědnosti za tvorbu a naplňování vzdělávacích cílů, kde úspěšnost vzdělávacího procesu nemusí nebo nemá být posuzována vzhledem $\mathrm{k}$ poněkud abstraktním vnějším standardům, stanoveným často byrokraticky, kde je naopak žádoucí autoevaluace na základě objektivních, srovnatelných kritérií.

Všeobecná platnost výše popsaných trendů a také fakt, že jsou přijímány a podporovány jako principy transformace vzdělávacích systémů na evropské i národní úrovni, souvisí s historickým kontextem, současným stavem a vyhlídkami demokratického uspořádání společnosti, globalizačními procesy atd. V současném období, které někteří autoři nazývají "tekutou modernitou" dochází na různých úrovních a v rozmanitých oblastech života společnosti k uvolňování vertikálních mocenských struktur a vazeb, a naopak se rozvíjejí horizontální vztahy. Tento vývoj je doprovázen decentralizací odpovědnosti, a pro nový systém uspořádání a fungování se teprve postupně vytvářejí pravidla a regulační rámce (Pehe, 2006). V souvislosti s tím dochází také k proměně vzdělání, jež má nově připravovat $k$ převzetí této odpovědnosti - i zde se proměňuje institucionální systém, škola přebírá iniciativu $v$ tvorbě svých vzdělávacích kurikulí a koncepcí, učitel je více odpovědný za obsah výuky a současně jeho vztah ke studentům je spíše dialogický, partnerský. Teoretická východiska pro nové institucionální a metodické uspořádání vzdělávacího prostředí jsme se v prvním textu zde prezentovaném („Obecné vzdělávací kvality a pojem kompetence") pokusili nastínit.

Jak jsme ukázali v druhém textu „Kompetence v environmentálním vzdělání", s decentralizací odpovědnosti ve vzdělávání (všeobecném, a zvláště v oblasti environmentální) jsou spojeny nové nároky na edukační prostředí i vzdělavatele/vzdělávaného. Ve sféře výuky již nejde o to, aby byl žák připraven na svou budoucí, dobře definovanou úlohu $v$ hierarchicky uspořádané společnosti (tedy výuka nemá být orientována na tento výsledek, „produkt") - má být nastartován proces celoživotního učení, počíá se totiž s nejistotami a změnami v pracovním zařazení. Cílem je

\footnotetext{
${ }^{9}$ Jedním z explicitně vyjádřených motivů pro formulaci klíčových kompetencí v programu DeSeCo je koncept udržitelného rozvoje: „Udržitelný rozvoj a sociální soudržnost významně závisí na kompetencích, kterými disponuje naše populace - a kterým je třeba rozumět tak, že pokrývají znalosti, dovednosti, postoje a hodnoty." (Ministři školství OECD, cit. na str. 4 studie) Viz program OECD „Definition and Selection of Competencies" (2005).
} 
tedy samotné učení, proces, který má transformativní povahu, nebot' se v průběhu života proměňuje spolu se svým subjektem: žákem, studentem, člověkem. V praktické rovině to znamená, že v profesní sféře, tedy v oblasti přípravy učitelů, ale i ve sféře učení, u žáků a studentů, je nutné otevírat prostor nebo vytvářet "kapacity" pro samostatnou práci. K nim patři schopnosti plánovat vlastní činnost (výuku/učení), zhodnotit své výsledky; stále se učit a zlepšovat další postup, a to na základě přímé zkušenosti a její reflexe. Místo všeobecně platných standardů a kritérií pak tomuto samostatnému zlepšování kvality činnosti (výuky/učení) napomáhají spíše př́klady dobré praxe a vzájemný dialog o výsledcích, jejich přednostech, chybách a nedostatcích. Takto nasměrované vývojové trendy odpovídají tzv. dynamické vzdělávací kultuře a teorii reflexivního učení, kterou jsme v závěru prvního článku stručně popsali. V rovině politické, ale znovu i vzdělávací, jsou uvedené principy spojeny s péčí o demokratické struktury na všech úrovních - cílem je zabezpečit rovnováhu mezi rưznými pohledy či přístupy.

V celkové proměně základních společenských paradigmat, kdy funkce společnosti již není založena na pouhém zvládání technických, instrumentálně založených problémů a respektu $k$ autoritám různého druhu, ale spíše na samostatném rozhodování, se proměňuje škála důrazů na preferované individuální vlastnosti a dispozice člověka. $V$ této rovině začíná hrát daleko silnější roli tvưrčí přístup (ve sféře intelektuální), a především schopnost si utvářet vlastní etická stanoviska, hledat pohnutky pro jednání nezávislé na většinovém názoru a obecné společenské praxi. Ve výuce/učení tak jde stále více o afektivní dimenzi, o to, aby člověk byl vybaven kompetencemi, které by odrážely nejen nabyté znalosti a dovednosti, ale i morálně založené postoje, k nimž se může dopracovat v průběhu celoživotního procesu učení.

Změny se projevují nakonec také v hodnocení kvality vzdělávání, které se orientuje ne již na (statické) výsledky, ale na (dynamické) procesy vyjádřené jako schopnosti využívat znalostního aj. potenciálu $\mathrm{v}$ konkrétních situacích, tedy kompetence. Pro společenské i vzdělávací prostředí, které je stále více nastavováno na decentralizaci odpovědnosti, jsou kompetence hlavním vzdělávacím cílem, nebot vybavují jednotlivé subjekty schopností samostatného rozhodování a jednání. Svou povahou poukazují na hlediska, ze kterých posuzujeme kvalitu vzdělání, a mohou se tedy stát obecným rámcem a základem pro ustavení systému kritérií nebo indikátorů vzdělávací procesy popisujících a hodnotících. Takto mohou sloužit bud' souhrnně, nebo také pro určení a vymezení indikátorů dílčích, které by ukazovaly na jednotlivé prvky, aspekty nebo výstupy těchto procesů, tedy to, co $v$ tomto textu označujeme jako vzdělávací kvality. Když jsme ale zrekapitulovali stručně problémy s tímto koncepčním rámcem spojené, konstatovali jsme, že než budou některé zásadní otázky podrobněji teoreticky rozpracovány, zůstávají kompetence pro samotné hodnocení poněkud nejasným, nekonkrétním nástrojem - to souvisí s př́lišnou komplexitou a neurčitostí tohoto pojmu, což prozatím brání jeho operacionalizaci. Z výše popsaných důvodů je ovšem problematika kompetencí a jejich hodnocení velmi závažným a pro vzdělávací praxi užitečným výzkumným tématem.

Specifikem environmentální praxe je to, že celá tato oblast je velmi závislá na dosažení demokratického konsenzu v rámci rưznorodých diskurzů a názorů, a vzdělání takto orientované má proto mít silný komunikativní aspekt $v$ různých rovinách: v interdisciplinárním př́stupu, při zapojení různých subjektů z praxe do dialogu, v důrazu na rozvíjení schopnosti realizovat společnou prakticky orientovanou činnost nebo projekty atd. Pedagogické teorie vázané k ESD (zde se rozumí skutečně vzdělání pro udržitelný rozvoj, což je pro nás podmnožina environmentálního vzdělání) vycházejí ze všech těchto důvodů stále více z poznatků a př́stupů sociologie, a jsou aplikovány jakožto tzv. sociální učení (Wals, 2007). Tento vývoj velmi pravděpodobně významně obohatí pedagogiku jako teoretický obor a přispěje k proměně existujících vzdělávacích koncepcí i systémů v praxi.

$* * *$

Úvahy vedené (ve dvou spolu souvisejících textech) široce, v kontextu všeobecných vzdělávacích cílů a pedagogických nástrojů, poukázaly na určitou omezenost až 
neopodstatněnost přístupu opačného - tedy odvození obecných principů od cíle poměrně dílčího nebo $v$ určitém ohledu specifického. Nelze např́klad na základě požadavku, aby vzdělávací systém vedl žáky či studenty k proenvironmentálnímu chování, odvodit tezi: "Odpovědné environmentální chování ... je řadou autorů chápáno jako základní cíl environmentální výchovy." (jak navrhuje Činčera, 2009). Chování jako cíl výchovného procesu má velmi nepř́jemné behaviorální konotace. ${ }^{10} \mathrm{Na}$ druhé straně může ovšem poměrně dobře sloužit jako empirický základ poskytující nezbytnou evidenci o naplnění cílů, jež jsou stanoveny jinak (například jako kompetence). ${ }^{11}$ Mezi jednotlivými termíny používanými pro popis vzdělávacích cílů i nástrojů jejich hodnocení je pak třeba přísně rozliš̌vat: $v$ uvedeném prípadě konkrétně mít na paměti, že určitá kompetence je vzdělávací kvalitou, kdežto proenvironmentální chování může být dobrým indikátorem jejího dosažení, pokud vhodně stanovíme podmínky a meze jeho vypovídací schopnosti.

Abychom tyto důležité otázky dokázali promyslet $v$ širším kontextu, je třeba zvláště $v$ obdobích proměny vzdělávacích systémů se stále znovu vracet $k$ tradičním všeobecným základům vzdělání. Teprve pak je možno $\mathrm{k}$ pojmům, které $\mathrm{z}$ nich př́mo vycházejí nebo jsou $s$ nimi těsně spojené - jako tomu je $v$ našem př́padě $s$ pojmem kompetence - dospět na základě vlastní úvahy nebo analýzy; není nutné je přejímat jako hotový koncept odjinud. Pak se i vzdělání jako takové může stát sférou uvědomělého rozhodování, nikoli působení politických zájmů. Transformační procesy jsou totiž často výsledkem změn v sociálním prostředí, jež politici považují za natolik významné, že na ně musí právě vzdělání reagovat. To se pak má stát nástrojem, který by mohl zajištótovat behaviorální změny $v$ "sociálně žádoucím směru". Většina odborníkủ zabývajících se vzděláním obecně a environmentálním zvláště se ale shoduje $v$ tom, že tento instrumentální přístup nelze sladit s definicí samotného vzdělání; existuje velmi silný konsenzus ohledně toho, že školy nejsou organizace, které by měly být používány $\mathrm{k}$ řešení sociálních problémů (Jensen \& Schnack, 1997; Scott, 2002 In: Sleurs, 2004: 22). Pro tato řešení totiž neexistuje nějaký univerzální návod, předpis nebo standard, který by bylo možné předat, ve škole se mu naučit - objevují se, vyvstávají jako součást společného dialogu a konsenzu. $K$ tomuto novému výsledku společenského rozhodování je pak třeba dospět $v$ procesu, pro který by měl být člověk velmi dobře vybaven určitými kompetencemi, tedy znalostmi, dovednostmi, a především také postoji.

Diskuze $\mathrm{v}$ tomto textu rozvinutá se tak vrací zpět $\mathrm{k}$ původním východiskům a principům vzdělání, které soustřed'ují svou pozornost na člověka, jeho individuální rozvoj a životní orientaci. Tento rozměr lidského života vcelku pak souvisí s jeho celkovým smyslem, zahrnujícím zcela samozřejmě i vědomou odpovědnost za budoucnost nejen vlastní, ale i za příští stav společnosti. Svoboda rozhodování je pro uskutečnění této odpovědnosti podmínkou, prímo souvisí s morálním imperativem v ní obsaženým. Jakýkoli čin, rozhodnutí totiž spočivá na etických základech - ty jsou podstatou vize a zaměřenosti všeho lidského jednání.

10 Behaviorismus je přístup psychologických věd, který je založen na předpokladu, že vše, co organismus činí - včetně jednání, myšlení a cítění - může být z určitého hlediska redukováno na chování. Behaviorističtí teoretici definují učení jako nabývání nového chování a $v$ experimentální rovině určují podmiňování jako univerzální proces učení. Ústředním pojmem behaviorismu se stala adaptace, vyjadřující obecný princip vývoje a utváření chování.

Behaviorismus má své etické důsledky: znamená v podstatě, že nejsme za své jednání zodpovědní, lidská bytost je zbavena svobody. Behaviorální věda neslouží pouze ke studiu lidského chování, ale i k jeho předpovídání a manipulaci. Člověk je redukován na bytost víceméně biologickou, která může být "tvarována" požadovaným způsobem těmi, kdo umí nástroje rozvinuté behaviorismem používat efektivně.

${ }_{11} \mathrm{~V}$ tomto prípadě odvozuje evaluace svou opodstatněnost z očividně platného pořekadla: „The proof of the pudding is the eating", které ale neznamená, že co se týče pudingu, jde nám právě jen o zpưsob, jak jej konzumujeme, a že dokonce určitá kultura stolování je tím, o co je třeba ve výchově usilovat. 


\section{Literatura:}

- Allen, J., Ramaekers, G., \& Velden, Rolf van der., (2005) Measuring Competencies of Higher Education Graduates. Enhancing Alumni Research: European and American Perspectives. In D. J. Weerts \& J. Vidal (Eds.), New Directions for Institutional Research, Number 126, Summer 2005, Jossey-Bass (pp. 49-59). San Francisco.

- Bělecký, Z. (2004). Klíče ke školnímu vzdělávacímu programu. / Keys to school educational programme. Učitelské listy. Učitelské listy, 12(2004), 4-5. Retrieved from http://ucitelskelisty.cz/files/soubory/Inspiromat6.1.pdf

- Belz, H., \& Siegriest, M. (2001). Klíčové kompetence a jejich rozvíjení, Praha. Praha: Portál.

- Národní program rozvoje vzdělávání v České republice - 4. verze; III. Terciární vzdělávání (str. 43 - 52); Kap. 2. Cíle a struktura terciárního vzdělávání (2001). . Retrieved from http://www.msmt.cz/bila-kniha/narodni-program-rozvoje-vzdelavani-v-ceske-republice-bilakniha-2001

- Bloom, B. S. (1956). Taxonomy of Educational Objectives, Handbook I: The Cognitive Domain. New York: David McKay Co Inc.

- Činčera, J. (2008). Poslední verze Strategie vzdělávání pro udržitelný rozvoj České republiky - Připomínky J. Činčery. in the Czech Republic. Envigogika,3(1), 10-14712. Retrieved from http://www.envigogika.cuni.cz/index.php/Envigogika/article/view/254 http://dx.doi.org/10.14712/18023061.254

- Činčera, J. (2008). Evaluace program Ekoškola. Envigogika, 3(2), Retrieved from http://www.envigogika.cuni.cz/index.php/Envigogika/article/view/30 http://dx.doi.org/10.14712/18023061.30

- Činčera, J. (2009). Analýza průřezového tématu Environmentální výchova v Rámcovém vzdělávacím programu pro základní vzdělávání. Envigogika, 4(1), 10-14712. Retrieved from http://www.envigogika.cuni.cz/index.php/Envigogika/article/view/33 http://dx.doi.org/10.14712/18023061.33

- Dave, R. H. (1975). Developing and Writing Behavioural Objectives (R J Armstrong, ed.). : Educational Innovators Press.

- Delors, J. et al. (1997). Učení je skryté bohatství (formulovala Mezinárodní komise UNESCO Vzdělávání pro 21. století). Praha: UIV.

- Dlouhá, J. (2006). Environmentální vzdělání - pokus o systematické pojmenování problému. Envigogika, 1(1), Retrieved from http://www.envigogika.cuni.cz/index.php/Envigogika/article/view/7 http://dx.doi.org/10.14712/18023061.7

- Dlouhá, J. (2007). Pansofie v díle Jana Ámose Komenského. Envigogika, 2(2), Retrieved from http://www.envigogika.cuni.cz/index.php/Envigogika/article/view/18 http://dx.doi.org/10.14712/18023061.18

- Dlouhá, J. (2007). Ekologická etika - na pomezí etikety a revoluční ideologie. Envigogika, 2(1), Retrieved from http://www.envigogika.cuni.cz/index.php/Envigogika/article/view/13 http://dx.doi.org/10.14712/18023061.13

- Dlouhodobý záměr vzdělávání a rozvoje vzdělávání v ČR (2005). Praha: MŠMT ČR. Retrieved from http://aplikace.msmt.cz/pdf/JTDlouhodobyzamer05 appx.pdf

- Education Websites .. Retrieved from http://www.hyperion.ie/education.htm 
- Elliott, J. (1991) Environmental Education in Europe: Innovation, Marginalisation or Assimilation. In Environment, Schools and Active Learning, Centre for Educational Research and Development (pp. 25-27). Paris: OECD.

- Elliott, J. (1994) Developing Community-Focused Environmental Education through Action Research. In Evaluating Innovation in Environmental Education (pp. 38-38). Paris: Paris: OECD.

- Report on the concrete future objectives of education and training systems (2001). : European Council. Retrieved from http://ec.europa.eu/education/policies/2010/doc/concretefuture-objectives en.pdf

- Gough, N. (1987) Learning with Environments. In I. Robottom \& I. (Eds.), Environmental Education: Practise and Possibility. Geelong, Victoria: Deakin University Press.

- Harrow, A. (1972). A taxonomy of psychomotor domain: A guide for developing behavioral objectives. New York: David McKay.

- Hejdánek, L. (1994) Filosofický odkaz českého myslitele (doslov). In E. Rádl (Ed.), Útěcha z filosofie (pp. 80-205). Praha: Svoboda.

- Hučínová, L. (2005). Lisabonský proces - Vzdělávání a odborná příprava v Evropě do roku 2010. Klíčové kompetence - nová výzva z EU I. Metodický portál RVP, Retrieved from http://www.rvp.cz/clanek/76

- Hudecová, D. (2004). Revize Bloomovy taxonomie edukačních cílů Pedagogika. , LIV(3), 274283. Retrieved from http://aplikace.msmt.cz/DOC/NHRevizeBloomovytaxonomieedukace.doc

- Jensen, B. B., \& Schnack, K. (1997). The Action Competence Approach in Environmental Education. Environmental Education Research, 3(2), 163-178. Retrieved from http://www.tandfonline.com/doi/abs/10.1080/1350462970030205 http://dx.doi.org/10.1080/1350462970030205

- Kratwohl, D. R., Bloom, B. S., \& Masia, B. B. (1973). Taxonomy of Educational Objectives, the Classification of Educational Goals. Handbook II: Affective Domain. New York: David McKay Co., Inc.

- Kumpera, J. (1999). J.A.Komenského pro vzdělanost a humanitu dneška. Referát přednesený 15.listopadu 1999, v den výročí Komenského smrti, na Obecné poradě '99 - Sto let uprostred Evropy, pořádané Nadací Pangea $v$ Praze. . Retrieved from http://www.vialucis.cz/Komensky.htm

- Lisabonské cíle vzdělávání v evropském a národním kontextu (2003). Praha: MŠMT ČR. Retrieved from http://www.et2010.cz/eu-dokumenty.php?doku=2003

- McKeown, R. (2002). Education for Sustainable Development Toolkit. . Retrieved from http://www.esdtoolkit.org

- Mayer, M., \& Losito, B. (2008). Comments by two Italian experts. Discussion Paper on Competence in Education for Sustainable Development. .

- Morin, E. (1999). Seven Complex Lessons in Education for the Future. Paris: UNESCO.

- Oecd, (2005). Definition and Selection of Competencies" 1997-2002. . Retrieved from http://www.oecd.org/dataoecd/47/61/35070367.pdf

- Palouš, R. (1994). Stáŕí je nedělí života. Velký učitel dovede studenty až tam, kde je sám hledajícím. Vesmír, 73(634), 634-1994.

- Palouš, R. (1994). Česká zkušenost. Komenský, Bolzano, Masaryk, Patočka. Studie: Komenského škola stárí a založení gerontagogiky (1978). Praha: Academia. 
- Pehe, J. (2006) Globální rízení a globální správa (sítová řízení a horizontální alternativy. In Dlouhá, J., Dlouhý, J., Mezřický, V. (Ed.), Globalizace a globální problémy. Sborník textů $k$ celouniverzitnímu kurzu 2005 - 2007 (pp. 123-132). : Univerzita Karlova v Praze, COžP. ISBN. Retrieved from http://www.czp.cuni.cz/knihovna/globalizace.pdf

- Posch, P. (1994) Networking in environmental education. In Evaluating Innovation in Environmental Education. Paris: OECD (pp. 69-87). Paris: OECD.

- Posch, P. (1994). The Study "Environment and School Initiatives\&amp;quot; Phase One. In: Evaluating Innovation in Environmental Education. Paris: OECD.

- Průcha, J. (2000). Přehled pedagogiky: úvod do studia oboru. Praha: Portál.

- De_Raad, B., \& Schowenburg, H. C. (1996). Personality in learning and education: A review. European Journal of Personality, 10(5),

- Reason, P. (1988). Human Inquiry in Action. London: Sage.

- Sarkozi, R. (2006). Vady na krase ramcovych vzdelavacich programu II - Prilis mnoho slov. eská škola, 2006(5), Retrieved from http://www.ceskaskola.cz/Ceskaskola/AR.asp?ARI=102829\&CAI=2124

- Simpson, E. J. (1972). The Classification of Educational Objectives in the Psychomotor Domain. Washington, DC: Gryphon House.

- Schneckenberg, Dirk \& Wildt, Johannes, (2006) Understanding the Concept of eCompetence for Academic Staff. In Mac Labhrainn, I., McDonald Legg, C., D. Scjmeclemberg, \& J. Wildt (Eds.), The Challenge of eCompetence in Academic Staff Development (pp. 29-35). Galway: NUI Galway. Retrieved from http://www.ecompetence.info/uploads/media/ch3.pdf

- Schön, D. A. (1983). The Reflective Practitioner. London: Temple Smith.

- Scott, W. (2002). Education and Sustainable Development: challenges, responsibilities, and frames of mind. The Trumpeter, 18(1), Retrieved from http://trumpeter.athabascau.ca/index.php/trumpet/article/view/123/134

- $\quad$ Sleurs, W. (2008). Competencies for ESD (Education for Sustainable Development) teachers. A framework to integrate ESD in the curriculum of teacher training institutes. Comenius 2.1 project 118277-CP-1-2004-BE-Comenius-C2.1, Brussels, January 2008. Brussels.

- Sterling, S. (1996) Education in Change. In Huckle, J., Sterling, S. (Ed.), Education for Sustainability (pp. 18-39). London: Earthscan Publications Ltd.

- Stevenson, R. B. (1987) Schooling and Environmental Education.: Contradiction in Purpose and Practise. In I. Robottom (Ed.), Practise nad Possibility. Geelong, Victoria: Deakin University Press.

- Štech, S. (1999) Teoretické prístupy k vysokoškolské pedagogice.. In Vašutová, J. a kol. (Ed.), Vybrané otázky vysokoškolské pedagogiky (pp. 157-166). Praha: ÚVRŠ.

- Strategie UNECE pro vzdělávání pro VUR, 2005. Evropská hospodářská komise OSN. Přijato na Zasedání na vysoké úrovni Ministerstev školství a životního prostředí, Vilnius, březen 2005. In Strategie UNECE pro vzdělávání k udržitelnému rozvoji . . Retrieved from http://www.env.cz/AIS/web-pub.nsf/\$pid/MZPMNF8Z6SCK

- Tanner, R. T. (1974). Ecology, Environment and Education. Lincoln, Nebrasca: Professional Educators Publications.

- Steering, U. (2008). How Do Teachers Teach Sustainable Development? - A Panel on Competence in ESD in the Education Sector. Discussion Paper. : UNECE Steering Committee 
on Education for Sustainable Development. Retrieved from http://www.unece.org/env/esd/SC.EGI.htm

- UNECE Steering Committee on Education for Sustainable Development (2008b). The Reporting Format (Advance copy of ECE/CEP/AC.13/2008/2/Add.1) . . Retrieved from http://www.unece.org/env/esd/inf.meeting.docs/SC/SC3/ece.cep.ac.13.2008.2.add.1.e.AC.pdf

- UNECE (2008c) Discussion paper on competence in ESD in the education sector (ECE/CEP/AC.13/2008/7) Retrieved from http://www.unece.org/env/documents/2008/ece/cep/ac.13/ece.cep.ac.13.2008.7.e.pdf

- Václavík, V. (2004). Obecná pedagogika, Sylabus přednášek. : UHK. Retrieved from http://pdf.uhk.cz/uppe/old/OBEPG-syl2004.htm

- Wals, A. E. J. (2007). Social Learning Towards a Sustainable World: Principles, Perspectives, and Praxis. Wageningen, The Netherlands: Wageningen Academic Publishers.

- Walterová, E. (1998). Tvorba a realizace kurikula v evropské dimenzi, projekt „České vzdělávání a Evropa". Učitelské listy, 6(2), 5-7.

- Weinert, F. E. (2001) Defining and selecting key competences. Concept of Competence. A Conceptual Clarification. In Rychen, D.S. \& Salganik, L.H (Ed.),Defining and selecting key competencies. Cambridge (State of Washington) and Göttingen: Hogrefe \& Huber.

- Wilson-Hill, F., Law, B., \& Eames, C. . Action competence in New Zealand schools: Improving the capacity for understanding student learning in EFS. . Retrieved from http://www.edplus.canterbury.ac.nz/documents/research/AAEE\%20Action\%20Competence\% 20paper.pdf

\section{Př́lohy}

\section{Tabulka 2. Návrh kompetencí pro ESD v rámci přípravy indikátorů pro Strategii ESD UNECE}

(UNECE, 2008b, Př́loha 1 (b), Indikátor 2.1, sub-indikátor 2.1.2)

Určete míru, se kterou se kurikulum / studijní program explicitně vyrovnává s následujícími širokými oblastmi kompetencí podporujících ESD na různých úrovních vzdělání:

\begin{tabular}{|c|c|c|c|c|c|c|}
\hline Učit se poznávat & Předpokládané výstupy & & CEI & ú & ro & \\
\hline Podporuje vzdělání & - kladení analytických otázek / kritického myšlení & 0 & 1 & 2 & 3 & \\
\hline & - porozumění komplexitě / systémové myšlení & & & & & \\
\hline & - překonávání obtíží / řešení problémů & & & & & \\
\hline & - zvládání změn / kladení otázek & & & & & \\
\hline & $\begin{array}{l}\text { - tvưrčího myšlení / myšlení orientované na } \\
\text { budoucnost }\end{array}$ & & & & & \\
\hline & $\begin{array}{l}\text { - pochopení mezioborových vztahů / holistický } \\
\text { př́stup }\end{array}$ & & & & & \\
\hline & - další (libovolný počet) & & & & & \\
\hline
\end{tabular}




\begin{tabular}{|c|c|c|c|c|c|c|c|}
\hline & - & & & & & & \\
\hline \multirow{9}{*}{$\begin{array}{l}\text { Učit se jednat } \\
\text { Podporuje vzdělání } \\
\text { schopnost: }\end{array}$} & Předpokládané výstupy & & & & & & \\
\hline & $\begin{array}{l}\text { - aplikace naučeného v různých životních } \\
\text { kontextech }\end{array}$ & $\mathbf{0}$ & 1 & 2 & 3 & 4 & 5 \\
\hline & - rozhodování, zahrnutí nejistot & & & & & & \\
\hline & - zvládání krizí a rizik & & & & & & \\
\hline & - přijetí odpovědnosti & & & & & & \\
\hline & - jednání se sebeúctou & & & & & & \\
\hline & - jednání s přesvědčením & & & & & & \\
\hline & - další (libovolný počet) & & & & & & \\
\hline & - & & & & & & \\
\hline \multirow{7}{*}{$\begin{array}{l}\text { Učit se být } \\
\text { Podporuje vzdělání } \\
\text { schopnost/vlastnosti: }\end{array}$} & Předpokládané výstupy & & & & & & \\
\hline & - sebejistota & 0 & 1 & 2 & 3 & 4 & 5 \\
\hline & - sebevyjádření a komunikace & & & & & & \\
\hline & - vyrovnávání se se stresem & & & & & & \\
\hline & - určit a vyjasnit hodnoty & & & & & & \\
\hline & - další (libovolný počet) & & & & & & \\
\hline & - & & & & & & \\
\hline \multirow{8}{*}{$\begin{array}{l}\text { Učit se žít } \\
\text { společně } \\
\text { Podporuje vzdělání } \\
\text { schopnost: }\end{array}$} & Předpokládané výstupy & & & & & & \\
\hline & - jednání s odpovědností & 0 & 1 & 2 & 3 & 4 & 5 \\
\hline & - jednání s respektem k druhým & & & & & & \\
\hline & $\begin{array}{l}\text { - určení zainteresovaných osob (skupin) a jejich } \\
\text { zájmů }\end{array}$ & & & & & & \\
\hline & - spolupráce / práce v týmu & & & & & & \\
\hline & - účast v demokratickém rozhodování & & & & & & \\
\hline & - vyjednávání a vytváření konsenzu & & & & & & \\
\hline & - distribuce odpovědnosti (subsidiarita) & & & & & & \\
\hline- & - další (libovolný počet) & & & & & & \\
\hline- & - & & & & & & \\
\hline
\end{tabular}


Tabulka 5. Srovnání psychomotorické domény v různých stádiích jejího rozvíjení s návrhem kompetencí v oblasti jednání, jak byly vymezeny pro environmentální vzdělání v dokumentu svázaném se Strategií ESD UNECE.

\begin{tabular}{|c|c|c|c|}
\hline $\begin{array}{l}\text { Psychomotorická } \\
\text { doména } \\
\text { (Simpson, 1972) }\end{array}$ & $\begin{array}{l}\text { Psychomotorická } \\
\text { doména } \\
\text { (Dave, 1975) }\end{array}$ & $\begin{array}{l}\text { Kombinované přístupy } \\
\text { pro vyučovací praxi }\end{array}$ & $\begin{array}{l}\text { Učit se } \\
\text { jednat } \\
\text { (UNECE, } \\
\text { 2008b) }\end{array}$ \\
\hline $\begin{array}{l}\text { Percepce - smyslová } \\
\text { stimulace } \\
\text { a schopnost užívat } \\
\text { smyslư pro řízení } \\
\text { pohybu }\end{array}$ & $\begin{array}{l}\text { Nápodoba - } \\
\text { pozorování } \\
\text { a přizpůsobování } \\
\text { pohybu podle vzoru; } \\
\text { výkon nemusí být } \\
\text { kvalitní }\end{array}$ & $\begin{array}{l}\text { Pohyb. Tato rovina cílů je } \\
\text { zaměřena na hrubou } \\
\text { motoriku. }\end{array}$ & $\begin{array}{l}\text { aplikace } \\
\text { naučeného } \\
\text { v rưzných } \\
\text { životních } \\
\text { kontextech }\end{array}$ \\
\hline $\begin{array}{l}\text { Nastavení - } \\
\text { pohotovost k akci; } \\
\text { zahrnuje mentální, } \\
\text { psychické } \\
\text { a emocionální složky }\end{array}$ & $\begin{array}{l}\text { Cvičení - po } \\
\text { instrukcích } \\
\text { a procvičování } \\
\text { schopnost vykonat } \\
\text { pohyb (akci). }\end{array}$ & $\begin{array}{l}\text { Manipulace. Úroveň } \\
\text { psychomotorických cílů } \\
\text { s názvem manipulace } \\
\text { zahrnuje cíle, které } \\
\text { předpokládají koordinaci } \\
\text { jemné motoriky. }\end{array}$ & $\begin{array}{l}\text { rozhodování, } \\
\text { zahrnutí } \\
\text { nejistot }\end{array}$ \\
\hline $\begin{array}{l}\text { Řízená odezva - } \\
\text { v raných stádiích } \\
\text { učení komplexní } \\
\text { dovednosti; zahrnuje } \\
\text { imitaci, pokus, chyby }\end{array}$ & $\begin{array}{l}\text { Zpřesňování - } \\
\text { přesnější výkon } \\
\text { pohybu, akce; méně } \\
\text { chyb }\end{array}$ & $\begin{array}{l}\text { Komunikace. Tato rovina } \\
\text { cílů zahrnuje vyjadřování } \\
\text { pocitů a myšlenek. }\end{array}$ & $\begin{array}{l}\text { zvládání krizí } \\
\text { a rizik }\end{array}$ \\
\hline $\begin{array}{l}\text { Mechanismus - } \\
\text { mezistupeň učení se } \\
\text { komplexní } \\
\text { dovednosti. Jde } \\
\text { o zvyk a jistotu ze } \\
\text { zkušenosti. }\end{array}$ & $\begin{array}{l}\text { Koordinace- } \\
\text { sladění více pohybů } \\
\text { či akcí, dosažení } \\
\text { harmonie a vnitřní } \\
\text { konsistence }\end{array}$ & $\begin{array}{l}\text { Tvorba. Tato úroveň je } \\
\text { nejvyšší v této doméně } \\
\text { a zároveň také nejvyšší ze } \\
\text { všech tří domén. } \\
\text { Předpokládá koordinaci } \\
\text { myšlení, učení a chování ve } \\
\text { všech třech doménách. }\end{array}$ & $\begin{array}{l}\text { přijetí } \\
\text { odpovědnosti }\end{array}$ \\
\hline $\begin{array}{l}\text { Komplexní odezva - } \\
\text { zahrnuje komplexní } \\
\text { vzorce pohybu. }\end{array}$ & $\begin{array}{l}\text { Automatizace - } \\
\text { přirozený výkon } \\
\text { pohybu, akce bez } \\
\text { přemýšlení a chyb. }\end{array}$ & & $\begin{array}{l}\text { jednání se } \\
\text { sebeúctou }\end{array}$ \\
\hline $\begin{array}{l}\text { Adaptace - } \\
\text { přizpůsobení } \\
\text { zvláštním } \\
\text { podmínkám. }\end{array}$ & & & $\begin{array}{l}\text { jednání s } \\
\text { přesvědčením }\end{array}$ \\
\hline $\begin{array}{l}\text { Tvorba - důraz na } \\
\text { tvořivost založenou } \\
\text { na rozvinuté } \\
\text { dovednosti. }\end{array}$ & & & \\
\hline
\end{tabular}


Časopis Envigogika vydává Centrum pro otázky životního prostředí UK. Vývoj časopisu je podpořen projektem OP VK Mezioborová sít udržitelného rozvoje.

Více najdete na internetových stránkách projektu mosur.czp.cuni.cz
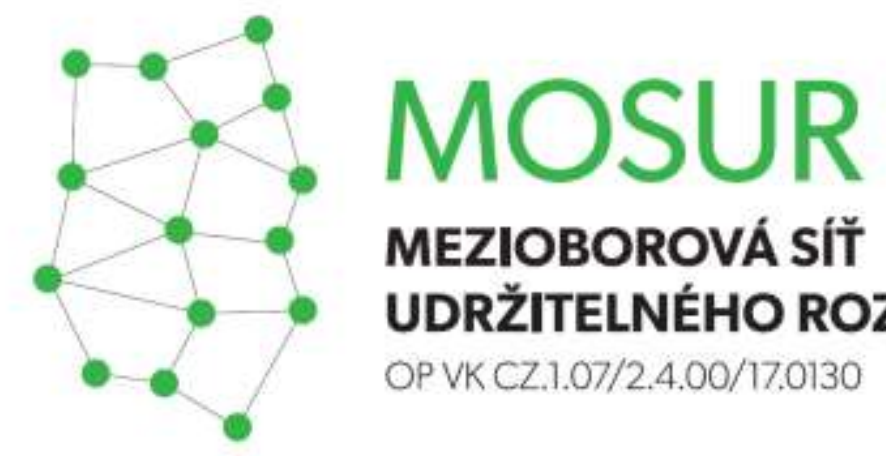

\section{MEZIOBOROVÁ SÍT} UDRŽITELNÉHO ROZVOJE

OP VK CZ.1.07/2.4.00/17.0130
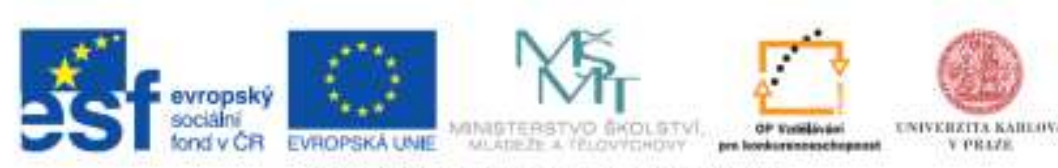

INVESTICE DO ROZVOJE VZDELAVANI 